\title{
The phosphatidylinositol synthase of proximal tubule cells
}

\author{
Carlos Galvao and James A. Shayman \\ Department of Internal Medicine, Division of Nephrology, University of Michigan and Veterans Administration Medical Center. \\ Ann Arbor, MI (U.S.A.)
}

(Received 24 August 1989)

Key words: Kidney; Proximal tubule cell; Phosphatidylinositol; (Rabbit)

\begin{abstract}
Phosphatidylinositol (PI) is a precursor for an important class of phospholipids, the phosphatidylinositol polyphosphates. Because renal myo-inositol levels may vary under both physiological (e.g., antidiuretic) and pathophysiological (e.g., diabetic) conditions, the formation of PI from CDP-diacylglycerol (CDP-DG) and myo-inositol via phosphatidylinositol synthase and the regulation of this enzyme have important implications for the cellular biology of renal epithelia. We sought to understand the role of PI synthase by determining its subcellular localization, kinetic properties and regulation in rabbit proximal tubule cells. Proximal tubule cells were isolated from New Zealand White rabbits. The subcellular synthesis of PI was assessed by I ${ }^{32}$ P]orthophosphate labelling with subsequent subcellular fractionation. Labelling of PI was time-dependent and consistent with the rapid incorporation of ${ }^{32} \mathrm{PO}_{4}$ into basolateral, brush-border, microsomal and nuclear fractions. Pulse-chase labelling of proximal tubule cells was consistent with the formation of PI in microsomal fraction of the proximal tubule cells in addition to both brush-border and basolateral membranes. Conversely, phosphatidylcholine, phosphatidylethanolamine and phosphatidylglycerol displayed radiolabelling patterns consistent with microsomal synthesis alone. The in situ formation of phosphatidylinositol was substantiated by the direct measurement of phosphatidylinositol synthase activity in basolateral, brush-border and microsomal fractions. The apparent $K_{\mathrm{m}}$ values for myo-inositol were $0.32 \pm 0.19,0.39 \pm 0.21$ and $0.23 \pm 0.05 \mathrm{mM}$, and for CDP-DG were $0.12 \pm 0.02,0.14 \pm 0.05$ and $0.12 \pm 0.02 \mathrm{mM}$ in basolateral, brush-border and microsomal fractions, respectively. $V_{\max }$ values for phosphatidylinositol formation were slightly, but not significantly greater, in microsomal than for plasma membrane fractions. Moreover, based on enzymatic enrichment data, plasma membrane PI synthase activity could not be explained by microsomal cross-contamination alone. PI synthase activity was inhibited by co-incubation with PI without differences among the cellular fractions. Intracellular myo-inositol concentration in the proximal tubule cells as measured by gas-liquid chromatography was $20.5 \mathrm{mM}$, significantly greater than the apparent $K_{\mathrm{m}}$ values for myo-inositol. In conclusion, the in situ synthesis of phosphatidylinositol occurs in several membrane fractions; the kinetic properties of phosphatidylinositol synthase appear to be similar in each fraction; and phosphatidylinositol synthase in proximal tubule cells is inhibited by its own formation product. These data suggest that myo-inositol concentration alone is unlikely to be an important regulator of the chemical mass of phosphatidylinositol at the levels of this polyol observed in rabbit kidney.
\end{abstract}

\section{Introduction}

The now classic pathway whereby inositol trisphosphate and diacylglycerol are produced from the hormone-stimulated hydrolysis of phosphatidylinositol bisphosphate $\left(\mathrm{PIP}_{2}\right)$ is well documented in the renal epithelia $[1,2]$ as well as many other non-renal tissues $[3,4]$. However, a clear understanding of the detailed

Correspondence: J.A. Shayman, Department of Internal Medicine, Division of Ncphrology, University of Michigan and Veterans Administration Medical Center, 1560A MSRB II, Ann Arbor, MI 48109-0676, U.S.A. kinetics of inositol lipid formation and degradation remains elusive. For example, it has yet to be clearly established whether concomitant hydrolysis of phosphatidylinositol 4-monophosphate and phosphatidylinositol occur in addition to phosphatidylinositol 4,5-bisphosphate following hormone-stimulated activation of phospholipase C. Observed changes in the radiolabeling of PI and PIP following phospholipase $\mathrm{C}$ activation have been explained in part on the rapid synthesis and conversion of these products to $\mathrm{PIP}_{2}$, possible in part because of the liberation of free myo-inositol from the dephosphorylation of inositol monophosphate. A necessary (although not sufficient) requirement for this model of hormone-stimulated inositol lipid hydrolysis, how- 
ever, is the demonstration of in situ phospholipid formation at the site of action of candidate agonists. This has not been demonstrated previously in renal epithelia.

Phosphatidylinositol is synthesized from CDP-diacylglycerol and myo-inositol by phosphatidylinositol synthase (CDP-DG : myo-inositol 3-phosphatidylinositol transferase, EC 2.7.8.11). The subcellular site of PI synthase, however, remains controversial. Phosphatidylinositol has been widely reported to be formed exclusively within the microsomal fraction of cells with subsequent insertion into the plasma membrane [5,6]. Recently, distinct PI synthase activities have been identified in both the plasma membrane and the endoplasmic reticulum of GH3 pituitary cells [7] consistent with the in situ production of PI within plasma membranes. Canine cardiac sarcoplasmic reticulum and plasma membrane have also been suggested to possess phosphatidylinositol synthase activity [8]. Other investigators, however, have been unable to confirm the existence of non-microsomal synthase activity in a variety of cell types [9]. We sought to evaluate this issue by investigating the formation of phosphatidylinositol in renal proximal tubule cells. These cells are amenable to similar studies, not only because of the ability to readily fractionate their subcellular components, but also because they possess two biochemically and physiologically distinct plasma membrane domains, the brush-border and basolateral membranes. Potential differences in hormonal responsiveness between these plasma membrane domains could therefore, in theory, be the product of differences in phosphatidylinositol metabolism.

\section{Materials and Methods}

New Zealand white rabbits of either sex were used. Collagenase type II was obtained from Worthington Biochemical (Freehold, NJ)). High-performance TLC 60 plates were from E. Merck (Montreal, Canada). Phospholipids standards including CDP-diacylglycerol were from Sigma (St. Louis, MO) or Sedary (Port Huron, MI). Tri-n-octylamine was from Aldrich Chemical. Freon was from Matheson Gas Products. $\left[{ }^{32} \mathrm{P}\right] \mathrm{Or}-$ thophosphate (carrier-free), myo- $\left[2-{ }^{3} \mathrm{H}\right]$ inositol and aqueous liquid scintillant were from Amersham (Arlington Heights, IL). L-chiro-Inositol standard was the generous gift of Dr. B.W. Agranoff (University of Michigan, Ann Arbor, MI). Tri-sil concentrate and Reacti-vials $(0.3 \mathrm{ml})$ were from Pierce Chemical.

\section{Proximal tubule cell isolation}

Cells were isolated from renal cortical homogenates following the protocol of Vinay et al. [10]. Briefly, rabbits were killed under pentobarbital anesthesia, the kidneys removed, decapsulated and cortical slices dissected free. Cortical sections were minced thoroughly and suspended in a buffer consisting (in $\mathrm{mM}$ ) of $\mathrm{NaCl}$ $115, \mathrm{KCl} 3.9, \mathrm{KPO}_{4} 1.2, \mathrm{MgSO}_{4} 1.2, \mathrm{MgCl}_{2}, \mathrm{CaCl}_{2} 2.6$, $\mathrm{NaHCO}_{3} 30$, glucose 5, butyrate 1, alanine 1, mannitol 2.5 and lactate 5. Thereafter, cells were subjected to collagenase digestion for $30 \mathrm{~min}$ at $37^{\circ} \mathrm{C}$. The digestate was then centrifuged at $30 \times g$ for $4 \mathrm{~min}$. The resultant pellet was resuspended in a solution containing $45 \%$ Percoll and gradient centrifugation was performed at $35000 \times \mathrm{g}$ for $30 \mathrm{~min}$. 'Band 4' representing proximal tubule cells was removed and resuspended in a $5 \mathrm{mM}$ Tris- $\mathrm{HCl}$ buffer ( $\mathrm{pH}$ 7.4). Cells were pelleted at low speed and resuspended in this buffer three times to remove the Percoll. The entire cell isolation procedure was conducted at $4^{\circ} \mathrm{C}$.

\section{Membrane vesicle preparation}

Brush-border and basolateral membranes were prepared as described by Morrison and Pascoe [11]. An aliquot of the proximal tubule cell suspension in buffer was homogenized in a tissuemizer for four $30 \mathrm{~s}$ bursts at full speed while on ice. The homogenate was filtered through a $40 \mu \mathrm{m}$ nylon mesh and the filtrate was centrifuged at $3500 \times \mathrm{g}$ for $5 \mathrm{~min}$ at $4^{\circ} \mathrm{C}$. The supernatant was saved and $\mathrm{MgCl}_{2}$ added to achieve a final concentration of $10 \mathrm{mM}$. The solution was then allowed to stand on ice for $15 \mathrm{~min}$. The resultant pellet contained crude basolateral membranes and the supernatant brush-border membranes.

The supernatant was centrifuged at $35000 \times \mathrm{g}$ for 30 min and the resultant pellet was resuspended in a volume of $300 \mathrm{mM}$ mannitol and $5 \mathrm{mM}$ Tris- $\mathrm{HCl}$ buffer (pH 7.5). It was then centrifuged twice at $35000 \times g$ for $30 \mathrm{~min}$ at $4^{\circ} \mathrm{C}$. The resultant pellet was resuspended in $30 \mathrm{vol}$ of $150 \mathrm{mM} \mathrm{NaCl}, 50 \mathrm{mM}$ Tris- $\mathrm{HCl}(\mathrm{pH} 7.4)$ and $10 \mathrm{mM} \beta$-mercaptoethanol and subjected to a single Polytron burst. EDTA was added to yield a final concentration of $15 \mathrm{mM}$ and the solution was stirred on ice for $10 \mathrm{~min}$. Percoll was then added to yicld a final concentration of $15 \%$ and the solution was centrifuged at $25000 \times \mathrm{g}$ for $30 \mathrm{~min}$ at $4^{\circ} \mathrm{C}$. The second band from the top was recovered as enriched basolateral membrane. This fraction was removed, resuspended in the latter buffer without Percoll and centrifuged at 34000 $\times g$. The final pellet was used as enriched basolateral membranes.

\section{Subcellular fractions preparation}

The further subcellular fractionation of proximal tubule cells followed an adaptation of a protocol of Seyfred and Wells as originally described for hepatocytes [12]. Aliquots of the proximal tubule cell suspended in homogenizing buffer (HB) were homogenized twice in a tissuemizer for $30 \mathrm{~s}$ at $4^{\circ} \mathrm{C}$. This buffer consisted of $250 \mathrm{mM}$ sucrose, $1 \mathrm{mM}$ EDTA, $10 \mathrm{mM}$ $\mathrm{NaN}_{3}, 20 \mathrm{mM} \mathrm{NaF}, 75 \mathrm{mg} / 1$ phenylmethylsulfonyl fluoride and $10 \mathrm{mM}$ Tricine ( $\mathrm{pH} \mathrm{8.0)}$. The homogenate 
was then centrifuged at $1500 \times g$ for $5 \mathrm{~min}$, the supernatant removed and the pellet was resuspended in the same homogenizing buffer. The suspension was respun at $1500 \times g$ and the resultant supernatant was combined with that of the first centrifugation. The resultant pellet contained the nuclear fraction and was resuspended in $25 \mathrm{ml}$ of $\mathrm{HB}$ containing $20 \%$ Percoll and centrifuged at $10000 \times g$ for $20 \mathrm{~min}$. The pellet was further suspended in $10 \mathrm{ml}$ of a buffer consisting of (in $\mathrm{mM}$ ) sucrose $250, \mathrm{MgCl}_{2} 10$, Tricine $10(\mathrm{pH} \mathrm{8.0)}$. This suspension was centrifuged at $1500 \times \mathrm{g}$ for $5 \mathrm{~min}$, the supernatant discarded and the pellet was sequentially resuspended in $2 \mathrm{ml}$ of the latter buffer and to this was added $8 \mathrm{ml}$ of a buffer consisting of sucrose $2.3 \mathrm{M}$, $\mathrm{MgCl}_{2} 10 \mathrm{mM}$, Tricine $10 \mathrm{mM}(\mathrm{pH} 8.0$ ). This mixture was then centrifuged at $100000 \times g$ for $60 \mathrm{~min}$; the final pellet was recovered as the nuclear fraction.

The combined supernatants frm the initial spins were sequentially centrifuged at $3600 \times g$ for $5 \mathrm{~min}$, the resultant supernatant and pellet contained the crude microsomes and mitochondria, respectively.

The pellet containing the mitochondria was resuspended in $5.5 \mathrm{ml}$ of $\mathrm{HB}$ and to it $4.5 \mathrm{ml}$ of Percoll was added and the mixture centrifuged at $10000 \times g$ for 20 min. The resultant pellet was diluted in $10 \mathrm{ml}$ of $\mathrm{HB}$ and centrifuged at $3600 \times \mathrm{g}$ for $5 \mathrm{~min}$. The final pellet was recovered as the enriched mitochondria.

The supernatant containing the microsomes was centrifuged at $18000 \times g$ for $10 \mathrm{~min}$, the pellet was discarded and the supernatant was spun at $100000 \times g$ for $60 \mathrm{~min}$. The final pellet was recovered as the enriched microsomes.

\section{Assessment of fraction enrichment}

Marker enzymes were used to assess the purity of each fraction. These included fructose 1,6-bisphosphatase [13], $\mathrm{Na}^{+} / \mathrm{K}^{+}$-ATPase [14], alkaline phosphatase [15], cytochrome- $c$ reductase [16], succinate dehydrogenase [16], and DNA [17] for whole proximal tubule cell, basolateral membrane, brush-border membrane, microsomal, mitochondrial and nuclear fractions, respectively. Substrates for each enzyme marker were fructose 1,6-phosphate for fructose 1,6-bisphosphatase, ATP for $\mathrm{Na}^{+} / \mathrm{K}^{+}$-ATPase, $p$-nitrophenol for alkaline phosphatase, cytochrome $c$ reduced for cytochrome-c reductase and succinate oxidized for succinate dehydrogenase.

\section{${ }^{32} \mathrm{PO}_{4}$ labeling}

The pellet representing enriched proximal tubule cells was resuspended in a buffer consisting of (in $\mathrm{mM}$ ) Tris- $\mathrm{HCl}(\mathrm{pH} 7.4)$ 15.4, $\mathrm{NaCl} 140$ and glucose 5.6. Carrier-free $\left[{ }^{32} \mathrm{P}\right]$ orthophosphate was added to the cell suspension to attain a final concentration of $100 \mu \mathrm{Ci} / \mathrm{ml}$ for the standard labelling experiments and $500 \mu \mathrm{Ci} / \mathrm{ml}$ for the pulse-chase experiments. The mixture was then placed in a shaking water bath and gassed with $95 \% \mathrm{O}_{2}$ and $5 \% \mathrm{CO}_{2}$ at $37^{\circ} \mathrm{C}$. For standard labelling experiments, the cells were incubated for varying periods of time as detailed below. For pulse-chase labelling, the cells were exposed to radiolabel for $30 \mathrm{~min}$, pelleted at $500 \mathrm{rpm}$ for $3 \mathrm{~min}$ and then resuspended in a radiolabel-free Krebs-Henseleit buffer where the incubation was allowed to proceed for 30 and $60 \mathrm{~min}$. For both standard and pulse-chase labelling, subcellular fractionation was initiated by placing aliquots of suspended cells in $10 \mathrm{vol}$. of ice-cold HB.

\section{Phospholipid extraction, separation and identification}

Prior to lipid extraction, a small aliquot consisting of $5 \%$ of each fraction was removed for protein determination utilizing the fluorescamine reagent [18]. Bovine serum albumin was used as standard. Lipids were extracted by the addition of chloroform/methanol $/ 0.5 \mathrm{M}$ $\mathrm{HCl}(10: 20: 1, \mathrm{v} / \mathrm{v})$ to the isolated fractions. The mixture was vortexed and centrifuged at $270 \times g$ for $10 \mathrm{~min}$ at $4^{\circ} \mathrm{C}$ to effect phase separation. The upper phase was removed, the protein pellet at the interface deflected and the lower phase recovered. Both upper and lower phases were back-extracted and the lower phases were pooled and evaporated to dryness under a stream of $\mathrm{N}_{2}$. The lipid extract was resuspended in $50 \mu \mathrm{l}$ of chloroform/methanol $(1: 1, \mathrm{v} / \mathrm{v})$.

Extracted phospholipids and phospholipid standards were separated on high-performance thin-layer chromatography plates. Phosphatidylcholine, phosphatidic acid, phosphatidylethanolamine, phosphatidylserine and sphingomyelin were separated two-dimensionally. The first dimension utilized chloroform/methanol/ammonium hydroxide/water $(65: 35: 5: 0.6, \mathrm{v} / \mathrm{v})$ and the second dimension utilized chloroform/acetone/ methanol/acetic acid/water (45:19:10:15:2, v/v). In contrast to other reports [11], it was observed that phosphatidylinositol could not be reliably resolved from phosphatidylserine using this system. Phosphatidylinositol separations were thus conducted onc-dimensionally in a solvent system consisting of chloroform/ methanol $/ 40 \%$ methylamine $(65: 35: 10, \mathrm{v} / \mathrm{v})$. Phospholipids were identified both by autoradiography and by comparison to authentic standards. For routine analysis, plates were exposed to $I_{2}$ vapor, and phospholipids scraped and quantitated by liquid scintillation counting.

\section{Phosphatidylinositol synthase assay}

Synthase activity was assayed following the protocol of Imai and Gershengorn [7]. Isolated subcellular membranes were suspended in $50 \mu 1$ of buffer containing Tris- $\mathrm{HCl} 100 \mathrm{mM}$ (pH 7.5), EGTA $1 \mathrm{mM}, \mathrm{MgCl}_{2} 3$ $\mathrm{mM}, \mathrm{MnCl}_{2} 3 \mathrm{mM}, 0.1 \%$ Triton $\mathrm{X}-100,0.1$ to $10 \mathrm{mM}$ CDP-dipalmitoylglycerol and 0.1 to $10 \mathrm{mM}$ myo-inositol containing $10^{6} \mathrm{dpm} / \mathrm{nmol}$ of myo-[2- $\left.{ }^{3} \mathrm{H}\right]$ inositol. The incubation proceeded for either 10 or $20 \mathrm{~min}$ at 
$37^{\circ} \mathrm{C}$ and was terminated by the addition of $1 \mathrm{ml}$ of chloroform/methanol/concentrated $\mathrm{HCl}(100: 100: 1$, $\mathrm{v} / \mathrm{v})$. Phase separation was facilitated by the addition of $0.25 \mathrm{ml}$ of $10 \mathrm{mM}$ EDTA. The lower phase was removed and the upper phase was back extracted with chloroform. The lower phases were then combined, evaporated to dryness under $\mathrm{N}_{2}$ and the $\left[{ }^{3} \mathrm{H}\right]$ phosphatidylinositol formed was separated by high-performance TLC as above. Phosphatidylinositol was identified by co-migration with authentic standards and quantitated by liquid scintillation counting.

\section{Myo-Inositol quantitation}

Isolated proximal tubule cells were resuspended in a phosphate-saline buffer ( $\mathrm{pH}$ 7.4) and pelleted at low speed to remove Percoll. The tissue pellet was homogenized in 7\% trichloroacetic acid and allowed to stand on ice for $5 \mathrm{~min}$. L-chiro-Inositol was added as an internal standard at $5 \mathrm{~mol} / \mathrm{mg}$ tissue protein. The suspension was subsequently centrifuged at $30 \times g$ for $5 \mathrm{~min}$ at $4^{\circ} \mathrm{C}$. The pellet was saved for protein determination and the supernatant was mixed with a solution of $26 \%$ tri-n-octylamine and Freon to remove the trichloroacetic acid. The suspension was well mixed and centrifuged at $270 \times \mathrm{g}$ for $10 \mathrm{~min}$ at $4{ }^{\circ} \mathrm{C}$ to affect phase separation. The upper phase was used for derivatization and mass measurement.

An adaptation of the method described by Rittenhouse [19] was employed. $50 \mu 1$ aliquots of tissue extracts obtained as above were applied to clean and dry reacti-vials. An equal volume of GC-grade pyridine was also added, vials were capped, vortexed and dried under a stream of $\mathrm{N}_{2}$. Two other rinses of pyridine were performed to assure complete removal of water. To the dried samples, $25 \mu 1$ of dry pyridine was added, the vials were capped, vortexed and then heated at $70^{\circ} \mathrm{C}$ for 15 min. This was followed by the addition of $25 \mu \mathrm{l}$ of a Tri-sil : pyridine mixture $(3: 10)$ to the still-warm samples which again were vortex-mixed and heated for 20 min at $70^{\circ} \mathrm{C}$. The samples were dried under $\mathrm{N}_{2}$ flow and resuspended in HPLC grade acetonitrile for GC injection.

Separation and detection of the trimethylsily derivatives of myo-inositol and L-chiro-inositol were performed on a Hewlett-Packard 5890 chromatograph with an SP-2380 capillary column (Supelco, Bellefonte, PA). Split injection $(33: 1)$ and flame ionization detection were employed. Nitrogen was used as the carrier gas at a flow-rate of $1.7 \mathrm{ml} / \mathrm{min}$. Injector and detector temperatures were $200^{\circ} \mathrm{C}$, column temperature was $150^{\circ} \mathrm{C}$ and ramped at $3 \mathrm{C}^{\circ} / \mathrm{min}$. Under these conditions $\mathrm{L}$ chiro- and myo-inositol eluted at 4.5 and $7.0 \mathrm{~min}$, respectively. myo-Inositol mass was calculated from the ratio of myo-inositol and L-chiro-inositol peak areas.

\section{Results}

The enrichments of the isolated subcellular fractions and whole tubule cell homogenates are displayed in Table I. Proximal tubule cells obtained from 'band 4' of the Percoll gradient centrifugation displayed a marked increase in fructose 1,6-bisphosphatase activity, comparable to that originally reported by Vinay [10]. Brush-border and basolateral membranes were enriched for alkaline phosphatase and $\mathrm{Na}^{+} / \mathrm{K}^{+}$-ATPase activity, respectively, and were comparably de-enriched for the microsomal, mitochondrial and nuclear markers. Cytochrome- $c$ reductase was a significant contaminant of

\section{TABLE I}

\section{Enzyme profiles and DNA determinations of subcellular fractions}

PTC denotes proximal tubular cells. Results are expressed as the mean \pm S.E. of micromol of substrate converted per min per mg of protein of at least three separate experiments. The numbers in parentheses refer to the specific activity of the enzyme relative to the proximal tubule cell homogenate for the subcellular fractions and relative to the cortical homogenate for the proximal tubule cells. Substrates are as indicated in the Materials and Methods section. DNA results represent triplicate determinations and are expressed as $\mu \mathrm{g}$ of DNA per $\mu \mathrm{g}$ of protein.

\begin{tabular}{|c|c|c|c|c|c|c|}
\hline Sample & $\begin{array}{l}\text { Fructose-1,6- } \\
\text { bisphosphatase }\end{array}$ & $\begin{array}{l}\mathrm{Na}^{+} / \mathrm{K}^{+} \\
\text {-ATPase }\end{array}$ & $\begin{array}{l}\text { Alkaline } \\
\text { phosphatase }\end{array}$ & $\begin{array}{l}\text { Succinate } \\
\text { dehydrogenase }\end{array}$ & $\begin{array}{l}\text { Cytochrome-c } \\
\text { reductase }\end{array}$ & $\begin{array}{l}\text { DNA } \\
\text { assay }\end{array}$ \\
\hline Cortical homogenate & 0.047 & & & & & \\
\hline PTC homogenate & $\begin{array}{l}0.117 \\
(2.4)\end{array}$ & $0.01+0.006$ & $0.41 \pm 0.10$ & $0.098 \pm 0.001$ & $0.054 \pm 0.005$ & 0.067 \\
\hline Basolateral membrane & & $\begin{array}{l}0.091 \pm 0.028 \\
(9.1)\end{array}$ & $\begin{array}{l}0.58 \pm 0.13 \\
(1.4)\end{array}$ & $\begin{array}{l}0.063 \pm 0.001 \\
(0.6)\end{array}$ & $\begin{array}{l}0.0175 \pm 0.005 \\
(0.3)\end{array}$ & 0.0 \\
\hline Brush-border membrane & & $\begin{array}{l}0.014 \pm 0.013 \\
(1.4)\end{array}$ & $\begin{array}{l}2.86 \pm 0.23 \\
(7.0)\end{array}$ & $\begin{array}{l}0.033 \pm 0.006 \\
(0.3)\end{array}$ & $\begin{array}{l}0.012 \pm 0.001 \\
(0.2)\end{array}$ & 0.0 \\
\hline Microsomes & & $\begin{array}{l}0.001 \pm 0.004 \\
(0.1)\end{array}$ & $\begin{array}{l}0.31 \pm 0.016 \\
(0.6)\end{array}$ & $\begin{array}{l}0.208 \pm 0.003 \\
(2.1)\end{array}$ & $\begin{array}{l}0.155 \pm 0.006 \\
(2.9)\end{array}$ & $\begin{array}{r}0.05 \\
(0.7)\end{array}$ \\
\hline Mitochondria & & $\begin{array}{c}0.0 \\
(0.4)\end{array}$ & $\begin{array}{l}0.19 \pm 0.001 \\
(3.3)\end{array}$ & $\begin{array}{l}0.328 \pm 0.004 \\
(2.0)\end{array}$ & $\begin{array}{l}0.109 \pm 0.10 \\
(2.0)\end{array}$ & 0.0 \\
\hline Nuclei & & $\begin{array}{l}0.001 \pm 0.004 \\
(0.1)\end{array}$ & 0.0 & $\begin{array}{l}0.200 \pm 0.001 \\
(2.0)\end{array}$ & $\begin{array}{l}0.055 \pm 0.003 \\
(1.0)\end{array}$ & $\begin{array}{l}0.335 \\
(5.0)\end{array}$ \\
\hline
\end{tabular}




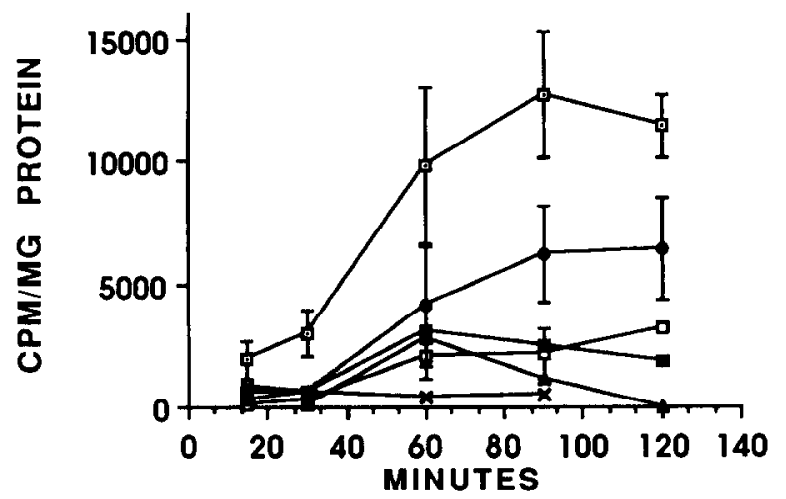

Fig. 1. Time-dependent labelling of phosphatidylinositol in different proximal tubule cell subcellular fractions. Proximal tubule cell homogenate, $\square$; brush-border membrane, @; basolateral membrane, $\square$; microsomes, $\square$; nucleus, $\Delta$; mitochondria, $\times$. Values represent the mean \pm S.E. of three experiments.

mitochondrial fractions, consistent with the presence of microsomal contamination; however, distinct differences in ${ }^{32} \mathrm{PO}_{4}$ incorporation occurred between microsomal and mitochondrial fractions, suggesting that a functionally significant separation had been accomplished (infra vide).

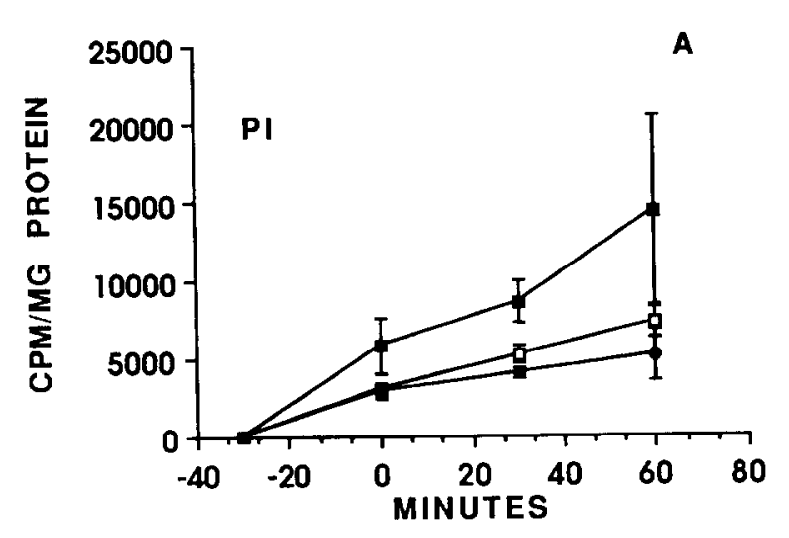

C

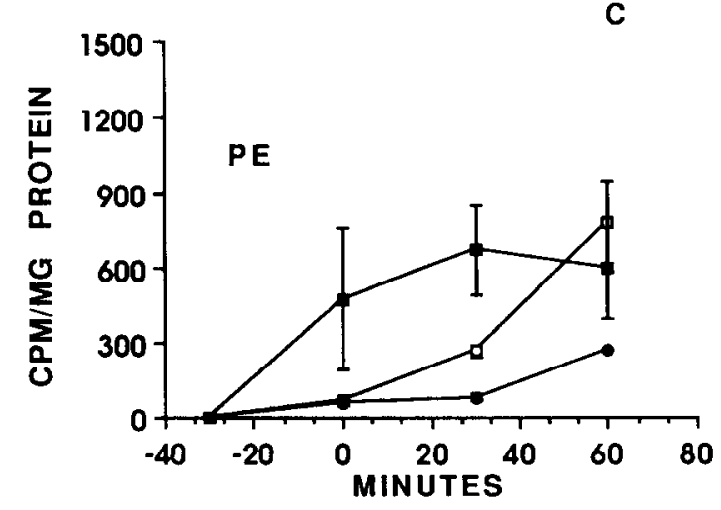

Fig. 1 displays the time-dependent labelling of phosphatidylinositol in the separated subcellular fractions expressed as cpm of ${ }^{32} \mathrm{PO}_{4}$ per $\mathrm{mg}$ of protein. Whole cell homogenates displayed the greatest increase in incorporated counts followed by brush-border, basolateral and microsomal membranes, respectively. Subcellular labelling was consistently observed to increase to 60 min and variably plateaued or fell by $90 \mathrm{~min}$. Of note was the time-dependent labelling in the nuclear fractions and the absence of mitochondrial labelling. These standard labelling studies were consistent with the presence of in situ formation of phosphatidylinositol in brush-border and basolateral fractions in addition to the microsomal membranes. This possibility was further assessed by pulse-chase labelling as shown in Fig. 2 . Following a $30 \mathrm{~min}$ incubation with ${ }^{32} \mathrm{PO}_{4}$, the radiolabel was removed and cells were further incubated in buffer. Microsomal labelling of PI rose to levels higher than those observed for either brush-border or basolateral membranes; $60 \mathrm{~min}$ following the removal of label microsomal PI continued to rise to comparably even greater levels (panel A). In contrast, markedly different patterns of labelling were observed for phosphatidylglycerol (panel B), phosphatidylethanolamine (panel C) and phosphatidylcholine (panel D). Here, microsomal radiolabelling appeared to precede the in-
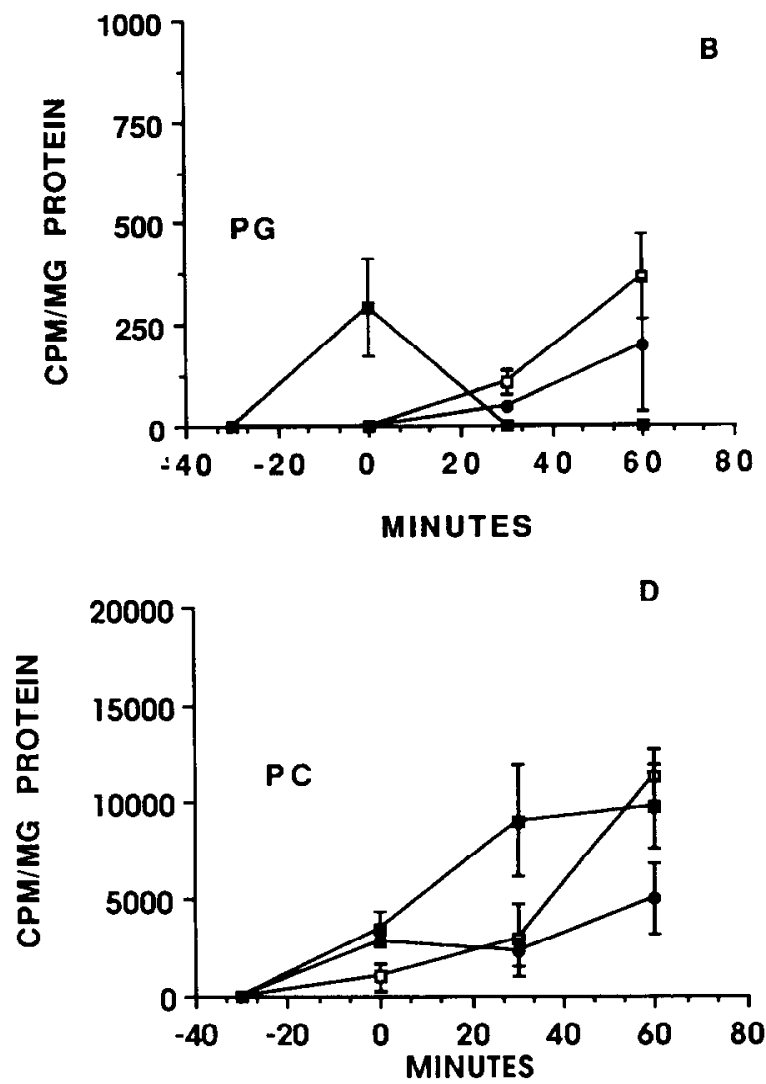

Fig. 2. Pulse-chase labelling of major phospholipids from proximal tubule cell subcellular fractions: (A) phosphatidylinositol; (B) phosphatidylglycerol; (C) phosphatidylethanolamine; (D) phosphatidylcholine. Brush-border membrane, e; basolateral membrane, $\square$; microsomes, $\square$. The data are from one of three representative experiments performed in triplicate. 
TABLE II

Kinetic measurements of phosphatidylinositol synthase

Comparisons of the apparent $K_{\mathrm{m}}$ values, maximal velocities and microsomal enrichments for microsomes, brushborder and basolateral membranes. The ratio of cytochrome-c reductase activity to phosphatidylinositol synthase activity is 3.4-times greater than in basolateral membranes and 4.0-times greater than that measured in brush-border membranes. Results are the mean \pm S.E. of five determinations. $V_{\max }$ and $K_{\mathrm{m}}$ values were not significantly different between membrane fractions by paired $t$-analysis.

\begin{tabular}{lllll}
\hline Sample & $\begin{array}{l}K_{\mathrm{m}} \\
(\mathrm{mM} \text { inositol })\end{array}$ & $\begin{array}{l}V_{\max } \\
\left(\mathrm{nmol} \mathrm{PI} \cdot \mathrm{mg}^{-1} \cdot \mathrm{min}^{-1}\right)\end{array}$ & $\begin{array}{l}\text { Cytochrome-c } \\
\text { reductase } \\
\left(\mu \mathrm{mol} \cdot \mathrm{mg}^{-1} \cdot \mathrm{min}^{-1}\right)\end{array}$ & $\begin{array}{l}\text { Cyto-c red/ } \\
V_{\max }\end{array}$ \\
\hline $\begin{array}{c}\text { Basolateral } \\
\text { membranes }\end{array}$ & $0.315 \pm 0.193$ & $0.118 \pm 0.041$ & 0.017 & 0.144 \\
$\begin{array}{c}\text { Brushborder } \\
\text { membranes }\end{array}$ & $0.386 \pm 0.210$ & $0.106 \pm 0.044$ & 0.012 & 0.113 \\
\begin{tabular}{c} 
Microsomes \\
\hline
\end{tabular} & $0.231 \pm 0.046$ & $0.209 \pm 0.045$ & 0.160 & 0.766 \\
\hline
\end{tabular}

corporation of ${ }^{32} \mathrm{PO}_{4}$ in both brush-border and basolateral membrane phospholipids, consistent with two potential interpretations. Fither there exists microsomal production of these lipids with subsequent shuttling to the plasma membrane domains, or in situ formation of these products in brush-border and basolateral membranes occurs at a rate which is significantly less than that in the microsomal compartment. Phosphatidylglycerol synthesis, however, demonstrated the absence of non-microsomal labelling immediately following the addition of the pulse label, but an increase in plasma membrane labelling was observed concomitant with the disappearance of microsomal labelling.

Further assessment of production of PI in the plasma membranes and the microsomal fractions of proximal tubule cells was carried out by direct measurement of PI

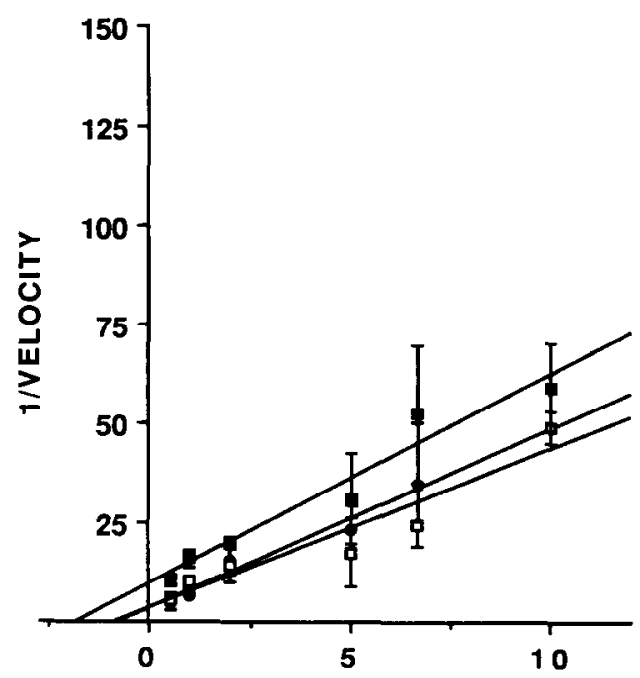

Fig. 3. Substrate vs. velocity profiles of microsomal ( $\square$ ), brush-border $(\bullet)$ and basolatcral membrancs $(\square)$ as a function of myo-inositol concentration. The data are from a representative experiment performed in triplicate. Correlation coefficients were $0.97,0.91$ and 0.95 , respectively. synthase activity. The apparent $K_{\mathrm{m}}$ for myo-inositol of the synthase in microsomal, brush-border and basolateral membranes was measured by varying the concentration of unlabeled myo-inositol from $100 \mu$ olar to 10 mmolar. By double-reciprocal plots (Fig. 3), the apparent $K_{\mathrm{m}}$ values of microsomal, brush-border and basolateral membranes were $0.23 \pm 0.05,0.39 \pm 0.21$ and $0.31 \pm 0.19 \mathrm{mM}$, respectively $(N=6)$. Similar studies were performed to assess the apparent $K_{\mathrm{m}}$ values for CDP-diacylglycerol in comparable fractions. $K_{\mathrm{m}}$ values for microsomal, brushborder and basolateral membranes were $0.12 \pm 0.02,0.14 \pm 0.05$ and $0.12 \pm 0.03$ $\mathrm{mM}$, respectively ( $N=4$ ), (Fig. 4). Table II displays the $V_{\max }$ values and compares them to the marker enzyme, cytochrome-c reductase, for the microsomal fractions. Although the maximal velocity of the microsomal synthase activity was slightly greater than that observed for

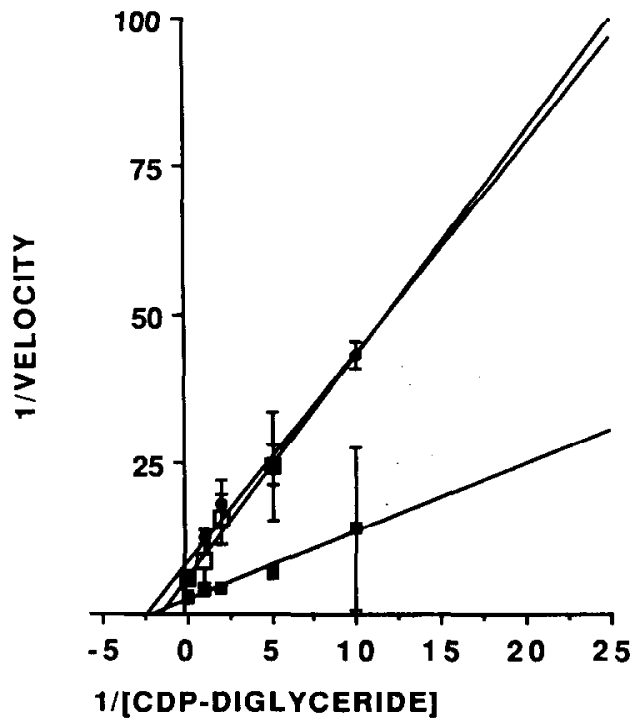

Fig. 4. Substrate vs. velocity profiles of microsomal, brush-border and basolateral membranes as a function of CDP-diacylglycerol concentration. Symbols are as indicated for Fig. 3. Data are from a representative experiment performed in triplicate. Correlation coefficients were $0.97,0.97$ and 0.98 , respectively. 


\section{TABLE III}

Effects of PI, PIP, PIP, and PC on PI synthase activities associated with proximal tubule cells subcellular fractions

Phospholipids were added to the incubation buffer as sonicated dispersions to make a $0.1 \mathrm{mM}$ solution prior to the addition of the fractions, PI, phosphatidylinositol; PIP, phosphatidylinositol monophosphate; PIP, phosphatidylinositol bisphosphate; PC, phosphatidylcholine. Results are the means of three determinations \pm S.E. ${ }^{*} P<0.05$ by paired $t$-test vs. control.

\begin{tabular}{llll}
\hline & \multicolumn{3}{l}{ PI synthase activity (percent of control) } \\
\cline { 2 - 4 } & $\begin{array}{l}\text { Basolateral } \\
\text { membrane }\end{array}$ & $\begin{array}{l}\text { Brush-border } \\
\text { membrane }\end{array}$ & Microsomes \\
\hline PI & $58 \pm 15^{\mathrm{a}}$ & $58 \pm 13^{\mathrm{a}}$ & $57 \pm 6.0^{\mathrm{a}}$ \\
PIP & $85 \pm 3.0$ & $88 \pm 5.0$ & $91 \pm 13$ \\
PIP & $89 \pm 16$ & $81 \pm 19$ & $76 \pm 1.0$ \\
PC & $90 \pm 10$ & $99 \pm 1.0$ & $97 \pm 8.0$ \\
\hline
\end{tabular}

the basolateral and brush-border membranes, this difference was not proportionate to the minor degree of microsomal contamination.

The inhibitory effects of phosphatidylinositol on its own formation was evaluated by coincubation of individual membrane fractions with increasing concentrations of phosphatidylinositol and the assay buffer. Exogenously added phosphatidylinositol was observed to inhibit the incorporation of myo- $\left[2-{ }^{3} \mathrm{H}\right]$ inositol into phosphatidylinositol in a concentration-dependent fashion with a $K_{\mathrm{i}}$ of approx. $0.05 \mathrm{mM}$ (data not shown). The same pattern of inhibition was observable for each fraction. Phosphatidylcholine, phosphatidylinositol monophosphate and phosphatidylinositol bisphosphate did not exert inhibitory effects under identical conditions (Table III).

Finally, proximal cellular myo-inositol content was measured in proximal tubule cells by gas-liquid chromatography. Cellular content was $53.3 \pm 4.3 \mathrm{nmol} / \mathrm{mg}$ protein $(n=4)$. Based on previous measurements of cell water content obtained using identical tubule isolation methods [33], estimated cellular myo-inositol concentration was $20.5 \mathrm{mM}$.

\section{Discussion}

Phosphatidylinositol synthase is a key enzyme in the inositol lipid pathway controlling both the substrate available for the formation of the phosphatidylinositol polyphosphates and serving as the first dedicated step in the utilization of cellular inositol. This enzyme was originally described in the kidney by Agranoff [21], however, the subcellular localization and regulation of phosphatidylinositol synthesis in renal epithelia remains poorly understood. The current study provides evidence that in fact phosphatidylinositol formation occurs at multiple subcellular sites and is not restricted to micro- somal fractions. Three types of experiment support this interpretation.

Radiolabelling experiments with carrier-free ${ }^{32} \mathrm{PO}_{4}$ were conducted and demonstrated time-dependent incorporation of the radiolabel into multiple subcellular fractions. This incorporation included not only the microsomal fraction but the plasma membrane and nuclear fractions as well. Under these conditions, the rate of incorporation of radiolabel was greatest in the brushborder membrane and did not appear to differ substantially among the microsomal, nuclear and basolateral membranes. These observations are consistent with in situ production of PI in non-microsomal membranes. Of additional interest was the observation that the rate of phosphatidylinositol synthesis appeared to be greater in brush-border than in basolateral membranes. This is contrary to comparable observations made by Molitoris and Simon [22]. Whether this disparity is due to species differences (rabbit vs. rat) or to other unappreciated factors is not apparent at present.

Also noteworthy was the apparent formation of phosphatidylinositol in the nuclear fractions. Similar observations have been recently reported in Friend erythroleukemia cells [23]. However, in the present study, additional efforts to strip the microsomal-rich nuclear envelope from the nuclei were not undertaken, rendering these data more difficult to interpret. However, the absence of depletion of nuclear isolates for cytochrome-c reductase make it likely that this labelling was in fact due to microsomal contamination.

A second line of evidence for non-microsomal phosphatidylinositol synthesis was the pulse-chase labelling performed on microsomal, brush-border and basolateral membranes. Each phospholipid studied revealed a pattern of radiolabeling typified by early microsomal incorporation which peaked or plateaued within $30 \mathrm{~min}$ of the removal of the pulse. This was followed by a rise in the incorporation of ${ }^{32} \mathrm{PO}_{4}$ into both the brush-border and basolateral fractions. This was most evident for phosphatidylglycerol, where no detectable labelling in non-microsomal fractions was evident until $30 \mathrm{~min}$ following the removal of the pulse. The exception to these observations was phosphatidylinositol; here, labelling of each fraction occurred at a constant rate over the full course of the experiment with no obvious relationship between the changes in microsomal labelling and plasma membrane labelling. The radiolabelled substrate for both phosphatidylinositol and phosphatidylglycerol formation is [ $\left.{ }^{32} \mathrm{P}\right] \mathrm{CDP}$-diacylglycerol [24]. Therefore, the discrepant patterns of labelling between phosphatidylinositol and phosphatidylglycerol provide strong support for the probable differences in sites of synthesis.

To further explore this hypothesis, PI synthase activity was examined in these three subcellular fractions. Enzyme activity was readily found in association with both plasma membrane domains and in the microsomal 
compartment. The enzyme displayed similar kinetics in each of these fractions. The apparent $K_{\mathrm{m}}$ values were comparable and the reaction was linear with respect to time and protein content of the sample. The observed $V_{\max }$ values for myo-inositol and CDP-DG were quantitatively, but only slightly lower, in the basolateral and brush-border membranes than in the microsomes consistent with a lower specific activity for the synthase in these fractions. This difference in activity, however, was not quantitatively significant to the point where plasma membrane activity could be accounted for by microsomal cross-contamination alone as indicated by the comparative ratios of the maximal velocities to the cytochrome- $c$ reductase activity. Finally, each fraction displayed comparable kinetics with respect to inhibition by PI and for the specificity of this inhibition.

Evaluated in concert, these data provide potentially useful insight into the regulation of phosphatidylinositol synthesis. The existence of distinct sites of phosphatidylinositol synthesis lends credence to the concept that there exist both hormone-sensitive and -insensitive pools of inositol lipids within cells $[25,26]$. The identification of hormone-responsive changes in both brush-border [27] and basolateral membranes [28] suggests that comparable distinctions may exist within the proximal tubule cell as well.

Of some interest is that the apparent $K_{\mathrm{m}}$ for myo-inositol in the fractions studied, 0.23 to $0.39 \mathrm{mM}$, is significantly below the encountered cellular concentration of myo-inositol. The intracellular myo-inositol concentration observed in the present study is in agreement with other reports of myo-inositol levels within the kidney [29] and other tissues [30]. Thus, under conditions in which cellular inositol levels fall (e.g., diabetes mellitus) [31-33], or in which inositol content may compensatorily rise (e.g., antidiuresis) [34], phosphatidylinositol synthesis may be unaffected, since myoinositol would be present at levels significantly greater than those required to saturate the enzyme.

Few studies have been conducted to assess in detail the kinetics of phosphatidylinositol synthesis and degradation in renal epithelia under abnormal metabolic conditions such as the diabetic environment. Cohen [30] has shown that rat glomerular phosphatidylinositol content did not fall when rats were rendered diabetic with streptozotocin, despite a significant drop in the glomerular myo-inositol content in these animals. Also supportive of the 'non-regulation' of phosphatidylinositol by cellular inositol levels is the observation that phosphatidylinositol synthase activity is inhibited by its formation product. This observation confirms that of Imai and Gershengorn in $\mathrm{GH} 3$ cells [35].

The present study supports the concept that in proximal tubule cells the regulation of phosphatidylinositol synthesis is tightly regulated and is unlikely to be affected by even considerable changes in cellular inositol content. The question as to whether or not a fall in intracellular myo-inositol concentration analogous to that observed in the glomeruli and nerves of diabetic animals or a rise in cellular inositol such as that observed under hyperosmolar conditions would affect phosphatidylinositol content in other renal tissues is an important issue requiring further investigation. Such studies, however, should be substantiated not only by direct chemical measurement of inositol lipid levels, as others have done, but by characterization of the phosphatidylinositol synthase under these conditions as well.

\section{Acknowledgement}

This project was supported by PHS grants DK 01784, DK 39255 and a Veterans Administration Merit Review award.

\section{References}

1 Rogers, S.A. and Hammerman, M.R. (1988) Proc. Natl. Acad. Sci. USA $85,4037-4041$.

2 Shayman, J.A. and Kirkwood, M.T. (1987) Biochem. Biophys. Res. Commun. 145, 1119-1125.

3 Abdel-Latif, A.A. (1986) Pharmacol. Rev. 38, 227-272.

4 Berridge, M.J. and Irvine, R.F. (1984) Nature 312, 315-321.

5 Bleasdale, J.E., Tyler, N.E. and Snyder, J.M. (1985) Lung 163, $345-359$.

6 Williamson, F.A. and Morre, D.J. (1976) Biochem. Biophys. Res. Commun. 68, 1201-1205.

7 Imai, A. and Gershenghorn, M.C. (1987) Nature 325, 726-728.

8 Kasinathan, C. and Kirchberger, M.A. (1988) Biochemistry 27, 2834-2839.

9 Monaco, M.E. (1987) J. Biol. Chem. 262, 13001-13006.

10 Vinay, P., Gougoux, A. and Llmieux, G. (1981) Am. J. Physiol. 241 (Renal Fluid Electrolyte Physiol. 10), F403-F411.

11 Morrison, A.R. and Pascoe, N. (1986) Kidney Int. 29, 496-501.

12 Seyfred, M.A. and Wells, W.W. (1984) J. Biol. Chem. 259, 12, $7659-7665$.

13 Latzko, E. and Gibbs, M. (1974) in Methods of Enzymatic Analysis, pp. 881-884, Academic Press, New York.

14 Yoda, A. and Yoda, S. (1980) Anal Biochem. 110, 82-88.

15 Bessey, O.A., Lowry, O.H. and Brock, M.J. (1946) J. Biol. Chem. 164, 321-329.

16 Evans, W.H. (1978) in Preparation and Characterisation of Mammalian Plasma Membranes; pp. 115-116, North-Holland Publishing, Amsterdam.

17 Labarca, C. and Paigen, K. (1980) Anal. Biochem. 102, 344-352.

18 Bohlen, P., Stein, S., Dairman, W. and Udenfriend, S. (1973) Arch. Biochem. Biophys. 155, 213-220.

19 Rittenhouse, S.E. (1987) Methods Enzymol. 141, 143-149.

20 Weinberg, J.M. (1985) Clin. Res. 33, 501A.

21 Agranoff, B.W., Bradley, R.M. and Brady, R.O. (1958) J. Biol. Chem. 233, 1077-1083.

22 Molitoris, B.A. and Simon, F.R. (1985) J. Membrane Biol. 83, 207-215.

23 Cocco, L., Gilmour, R.S. and Ognibene, A. (1987) Biochem. J. 248, 765-770.

24 Kennedy, E.P. (1986) in Lipids and Membranes: Past, Present and Future, pp. 171-206.

25 Fain, J.N. and Berridge, M.J. (1979) Biochem. J. 180, 655-661.

26 Monaco, M.E. and Woods, D. (1983) J. Biol. Chem. 258, 1512515129. 
27 Khalifa, S., Mills, S. and Hruska, K.A. (1983) J. Biol. Chem. 258, 14400-14406.

28 Hruska, K.A. et al. (1987) J. Clin. Invest. 79, 230-239.

29 Bagnasco, S. et al. (1986) J. Biol. Chem. 261, 5872-5877.

30 MacGregor, L.C. and Matschinsky, F.M. (1984) Anal. Biochem. 141, 382-389.

31 Cohen, M.P. (1986) Metabolism 35, 55-59.
32 Goldfarb, S., Simons, D.A. and Kern, E. (1986) Clin. Rus. 34, 725 A (Abstr.).

33 Greene, D.A. et al. (1988) Diabetes 37, 688-69,.

34 Burg, M.B. and Kador, P.F. (1988) J. Clin. Invest. 81, 635-610.

35 Imai, A. and Gershenghorn, M.C. (1987) J. Biol. Chem. 262, $6457-6459$ 